\title{
PERILAKU SOSIAL MAHASISWA DALAM KEHIDUPAN DI BARAK PADA KOTA PALANGKA RAYA
}

\author{
Students' Social Behaviour In Boarding Houses At Palangka Raya City
}

\author{
U.Z. Mikdar ${ }^{1}$ \\ 1Universitas Palangkaraya
}

\begin{abstract}
Abstrak
Di Kota Palangka Raya terdapat jenis barak konvensional, barak modifikasi dan barak semi-kost. Permasalahan dalam penelitian ini adalah (1) Bagaimana interaksi sosial mahasiswa dalam kehidupan di barak Kota Palangka Raya; dan (2) Perilaku sosial apa yang terbentuk di dalam proses interaksi sosial mahasiswa dalam kehidupan di barak Kota Palangka Raya. Metode yang digunakan kualitatif. Hasil penelitian ini adalah (1) Interaksi mahasiswa yang tinggal di barak konvensional dan barak semi kost menunjukkan perilaku sosial seperti tolong-menolong dan kekeluargaan. Sedangkan pada barak modifikasi ada kecenderung individualistis. Hal yang sama juga terjadi pada barak konvensional yang tidak ada dan/atau jauh dari pemiliknya cenderung penghuninya relatif lebih bebas; (2) Pola belajar mahasiswa yang tinggal di barak konvensional dan barak modifikasi cenderung hanya pada saat mau ujian dan ada tugas. Sedangkan pada barak semi kost, selain belajar di kampus juga belajar di barak (tempat khusus) yang telah disediakan oleh pemilik barak. Selain itu realita sosial yang menonjol, lunturnya nilai sosial pada kehidupan "barak" di Palangka Raya diantaranya adalah "kebebasan" hidup di barak, hamil di luar nikah dan perilaku minuman keras. Dalam menertibkan mahasiswa penghuni barak yang menyimpang, diperlukan peran masyarakat, pemilik kost, orang tua dan tokoh agama. Juga diperlukan sanksi yang ketat terhadap perilaku menyimpang.
\end{abstract}

Kata Kunci: Perilaku Sosial; Perilaku Menyimpang; Barak

\begin{abstract}
In the City of Palangka Raya there are types of conventional boarding houses, modification boarding houses and semiboarding boarding houses. The problems in this study are (1) How is the social interaction of students in life in the boarding houses of Palangka Raya City; and (2) What social behavior is formed in the process of social interaction of students in life in the boarding houses of Palangka Raya City. The method used is qualitative. The results of this study are (1) The interaction of students living in conventional boarding houses and semi-boarding boarding houses shows social behavior such as help and kinship. Whereas in the modified boarding houses there are individualistic tendencies. The same thing also happens with conventional boarding houses that are not present and / or far from their owners, the residents tend to be relatively more free; (2) The learning pattern of students living in conventional boarding houses and modification boarding houses tends to be only when they want to take exams and have assignments. While in the semi boarding boarding houses, in addition to studying at the campus also learn in the boarding houses (special places) that have been provided by the boarding houses owner. In addition, the salient social reality, the erosion of social values in the life of "boarding houses" in Palangka Raya include "freedom" to live in boarding houses, get pregnant outside of marriage and alcoholic behavior. In order to curb the deviant boarding houses residents, the role of the community, boarding houses, parents and religious leaders is needed. There is also a need for strict sanctions against deviant behavior.
\end{abstract}

Keywords: Social Behavior; Deviant Behavior; Boarding houses

\section{A. PENDAHULUAN}

Secara empirik yang teramati, bahwa keberadaan perguruan tinggi di perkotaan secara alami memunculkan pergerakan masyarakat dari pedesaan ke perkotaan berkembang secara signifikan. Keberadaan masyarakat di perkotaan yang diakibatkan dari adanya mobilisasi perpindahan anggota masyarakat dari satu pedesaan ke perkotaan tersebut menunjukkan tren peningkatan yang begitu besar. Signifikansi perpindahan tersebut, tentunya memiliki implikasi terhadap perubahan dan perilaku sosial 
pada setiap individu dan lingkungan sekitarnya.

Perubahan domain sosial, merupakan arah adanya pergerakan masyarakat ke perkotaan dengan membawa sejumlah karakteristik budaya dan perilaku sosial beragam tanpa sekat-sekat primordialisme yang ada, baik dari segi strata, tingkat, status, etika, bahkan norma sosial, suku, ras, agama, bahkan strata sosial dalam konteks kemajemukan masyarakat yang dianut sebelumnya.

Keadaan tersebut, akan mempengaruhi terhadap interaksi dengan masyarakat sekitarnya, baik yang dapat tunduk dan mematuhi akan kaidah-kaidah etika sosial yang berlaku pada masyarakat perkotaan tersebut, maupun adanya gesekan-gesekan yang berakhir pada persaingan yang kurang harmonis bahkan pada penyimpangan (deviasi) perilaku sosial masyarakat urban tersebut, hal ini terjadi di Kotakota besar termasuk di Palangka Raya dengan kondisi masyarakat yang heterogen.

Interaksi sosial pada lingkup perkotaan, tidak serta merta akan membawa suatu kesejahteraan yang diharapkan, disisi lain akan dipengaruhi oleh sejumlah perubahan lainnya termasuk perubahan perilaku. Perbedaan individu, karakter, dan asal daerah yang berpotensi terjadinya gesekan, persaingan, kompetisi, bahkan akan munculnya distorsi perilaku sosial lainnya, misalnya perkelahian, minuman keras, pembunuhan, pencurian, pemerkosaan, pencabulan, kecelakaan lalu lintas, narkoba dan penyimpangan lainnya.

Banyak orang terpukau dengan modernisasi, yang menyangka bahwa dengan modernisasi serta merta akan membawa kepada kesejahteraan. Ternyata di balik itu muncul yang dinamakan 'the agony of modernization, yaitu azab sengsara karena modernisasi' (Nugoroho Notosusanto; dalam Hawari, 1997:3). Gejala the agony of modernzation yang merupakan ketegangan psikososial itu, nampak dalam kehidupan masyarakat dengan indikator meningkatnya angka kriminal, kekerasan, perkosaan, judi, penyalahgunaan obat/narkotika/minuman keras, kenakalan remaja, perkelahian pelajar dan lain sebagainya (Hawari, 1997:3)

Selain itu realita sosial yang menonjol, adalah diantaranya lunturnya nilai sosial yang diterjadi pada kehidupan "barak" di Palangka Raya diantaranya adalah "kebebasan" hidup di barak, hamil di luar nikah, perilaku minuman keras yang berakhir kadang-kadang dengan perkelahian bahkan terjadi perkosaan, adanya over dosis penggunaan obat, mencoba minum baygon sebagai akibat kurangnya menerima tekanan-tekanan psikhis pada mahasiswa dan faktor lainnya.

Di Palangka Raya terdapat 161 barak dengan jumlah kamar 1673 buah, masing-masing barak konvensional 43 buah dengan 361 kamar, barak modifikasi 117 buah dengan 1282 kamar, dan barak semi kost 1 buah dengan 30 kamar yang berada di Jalan di Jalan Batu Hurun, Jalan Borneo, Jalan B.Koetin, Gg. Batu Nyaru, Jalan Bima, Jalan Mangku Rambang, Jalan Raden Patah, Jalan S. Badarudin, Jalan Cut Nya Dien, Jalan Cik Di Tiro, Jalan Tengku U kamar, Jalan Sam Ratulangi, Jalan Patimura.

"Barak" adalah sebuah atau sekumpulan gedung tempat tinggal tentara; asrama (tentara) polisi; bangsal khusus tempat merawat orang sakit (menular); bangunan yang bersifat sementara bagi pekerja (KBBI, 2007:107). Sedangkan di Kota Palangka Raya, "barak" dipahami sebagai tempat tinggal sewa siswa, mahasiswa maupun masyarakat lainnya yang sekolah, kuliah maupun bekerja di Kota Palangka Raya, yang pembayarannya di lakukan setiap awal bulan bagi yang bulanan, ataupun pembayaran yang dilakukan untuk jangka waktu satu tahun.

Sehubungan dengan fakta-fakta sosial yang telah dipaparkan di atas, maka sangat menarik bagi penulis untuk mengkaji perilaku sosial mahasiswa dalam kehidupan barak di Kota di Palangka Raya, kajian ini sangat penting, selain belum pernah ada penelitian untuk realita sosial tersebut, juga diperkuat pengalaman dan pengamatan sementara yang dialami penulis selama kurang lebih lima tahun ketika bertugas dalam bidang kemahasiswaan.

Berdasarkan uraian di atas, maka yang menjadi masalah dalam penelitian ini dapat dirumuskan sebagai berikut.

1. Bagaimana interaksi sosial mahasiswa dalam kehidupan di barak Kota Palangka Raya?

2. Perilaku sosial apa yang terbentuk di dalam proses interaksi sosial mahasiswa dalam kehidupan di barak Kota Palangka Raya?

\section{B. LANDASAN TEORITIS}

\subsection{Perilaku}

Menurut Melalatoa (Masinambow, 1997), kebudayaan dapat dipahami sebagai sistem ide, gagasan yang dimiliki suatu komunitas masyarakat lewat proses belajar, dan yang dijadikan acuan bagi tingkah laku dalam kehidupan sosial dari komunitas masyarakat bersangkutan. Ide, gagasan biasanya terkait dalam satu sistem yang dikenal dengan konsep sistem budaya. Sistem budaya adalah perangkat 
pengetahuan yang meliputi pandangan hidup, keyakinan, nilai, norma, aturan, hukum yang menjadi milik suatu masyarakat melalui proses belajar yang diacu untuk menata, menilai, dan menginterpretasi sejumlah benda dan peristiwa dalam beragam aspek kehidupannya (Bachtiar, 1984: 18).

George Homans dalam bukunya yang cukup terkenal, The Human Group, menjelaskan tentang perilaku sosial dalam suatu kelompok. Ada tiga konsep utama yang dipakai oleh Homans untuk menggambarkan kelompok kecil, yaitu kegiatan, interaksi, dan perasaan (sentiment) (Johnson, 1990: 61). Kegiatan adalah perilaku aktual yang digambarkan pada tingkat yang sangat konkret. Sebagian dari gambaran mengenai kelompok apa saja harus meliputi catatan mengenai kegiatankegiatan para anggotanya saja. Individu-individu dan kelompok-kelompok dapat dibandingkan menurut persamaan dan perbedaan dalam kegiatan-kegiatan mereka, dan dalam tingkatan penampilan dari berbagai kegiatan itu. Interaksi adalah kegiatan apa saja yang merangsang atau dirangsang oleh kegiatan orang lain. Individuindividu atau kelompok-kelompok dapat dibandingkan menurut frekuensi interaksi, menurut siapa yang mulai interaksi dengan siapa, menurut saluran-saluran dimana interaksi itu terjadi dan seterusnya. Perasaan, seperti yang sudah kita lihat, tidak didefinisikan, hanya sebagai suatu keadaan subyektif (seperti mungkin yang diharapkan menurut akal sehat), tetapi sebagai tanda yang bersifat eksternal atau yang bersifat perilaku yang menunjukkan suatu keadaan internal. Tanda-tanda, seperti keadaan internal yang ditunjukkannya bermacam-macam.

\subsection{Perilaku Sosial}

Untuk memahami perilaku seseorang, dalam ilmu sosial selama ini digunakan pendekatan behaviorisme, khususnya di bidang psikologis sosial. Behaviorisme dicetuskan oleh J. B. Watson (1914; dalam Hasym Nawawie, 2009:66), dengan didasarkan pada premis bahwa yang menjadi “bidang kajian psikologis manusia adalah perilaku dan aktivitas manusia. Seperti halnya positivisme logis, pandangan ini mengesampingkan semua konsep 'objektif' yang tidak dapat diambil secara langsung, misalnya sensasi, persepsi, citra, hasrat, bahkan pemikiran dan emosi karena kesemuanya didefinisikan secara subyektif (Fromm, 2001: 34, dalam Hasym Nawawie, 2009:66).

Teori ini memiliki bentuk-bentuk perilaku sosial sebagaimana dikutip oleh Wallace dan Wolft (1986: 145-186; dalam Hasym Nawawie, 2009:69).
Bentuk-bentuk perilaku sosial yang dimaksudkan adalah sebagai berikut;

1. Proposisi Keberhasilan

Dalam segala hal yang dilakukan oleh seseorang, semakin sering sesuatu tindakan mendapatkan ganjaran (mendatangkan respon yang positif dari orang lain) maka akan semakin sering pula tindakan akan dilakukan oleh orang yang bersangkutan.

\section{Proposisi Stimulus}

Jika suatu stimulus tertentu telah merupakan kondisi di mana tindakan seseorang mendapatkan ganjaran maka secara stimulus yang ada dengan stimulus tersebut akan semakin besar kemungkinannya bagi orang itu untuk mengulang tindakannya seperti yang ia lakukan pada waktu yang lalu.

\section{Proposisi Nilai}

Semakin bermanfaat hasil tindakan seseorang bagi dirinya maka akan semakin besar kemungkinan tindakan tersebut diulangi. Proposisi rasionalitas yang merupakan kombinasi tiga proposisi yang ada menyatakan bahwa didalam memilih suatu tindakan diantara alternatif tindakan yang mungkin dilaksanakan maka seseorang akan memilih yang paling menguntungkan dilihat dari segi waktu, nilai, hasil (V) dan perkembangan berdasar kemungkinan pencapaian hasil (P).

\section{Proposisi Kejenuhan-Kerugian}

Semakin sering seseorang menerima ganjaran yang istimewa maka ganjaran tersebut akan menjadi kurang bermakna.

\section{Proposisi Persetujuan Perlawanan}

a. Jika seseorang tidak mendapat ganjaran seperti ia inginkan atau mendapat hukuman yang tidak ia harapkan ia akan menjadi marah dan akan semakin besar kemungkinan bagi orang tersebut untuk mengadakan perlawanan atau menentang dan dari hasil tingkah laku semacam ini akan menjadi lebih berharga bagi dirinya.

b. Bila tindakan seseorang mendatangkan ganjaran seperti yang ia harapkan bahkan berlebihan atau tindakan tersebut tidak mendatangkan hukuman seperti keinginannya maka ia akan merasa senang dan akan semakin besar kemungkinannya bagi orang tersebut untuk menunjukkan tingkah laku persetujuan terhadap tingkah laku yang dilakukan, dan hasil tingkah laku semacam ini akan menjadi semakin berharga dari dirinya. 


\section{METODE PENELITIAN}

Dalam mengungkap fenomena tentang perubahan dan perilaku sosial mahasiswa di Kota Palangka Raya perlu metode dan pendekatan kualitatif. Dalam penelitian ini pemilihan sampel dilakukan secara purposive sampling. Penelitian ini dilaksanakan pada barak-barak yang dekat dengan lingkungan kampus dan termasuk dalam Kecamatan Jekan Raya Kota Palangka Raya. Proses pengumpulan data melalui observasi, Partisipasi (partisipant observer), wawancara dan dokumentasi. Model analisis data yang digunakan dalam penelitian ini adalah seperti yang dikembangkan oleh Strauss dan Corbin (1990:61-142) dalam Djunaidi Dhony (1997). Proses (Analisis) Coding yaitu: 1) Pengkodean Terbuka (Open Coding). 2) Pengkodean Terpusat (Axial Coding). 3) Pengkodean Terpilih (Selective Coding).

\section{PEMBAHASAN}

Perilaku menyimpang dalam barak dikarenakan ada peluang terjadinya perilaku menyimpang. Hal ini diperkuat dengan desain, bentuk barak yang secara fisik akan memberi peluang untuk secara bebas penghuni lainnya untuk mendekati ataupun masuk ke dalam kamar secara sembunyi ataupun disembunyikan penghuninya, termasuk acuh tak acuh sesama penghuni serta kurangnya perhatian dan pengawasan dari pemilik barak itu sendiri. Dalam penelitian ini akan dibahas perilaku mahasiswa dalam kehidupan barak di Kota Palangka Raya

\subsection{Interaksi Sosial Mahasiswa dalam Kehidupan di Barak}

Interaksi sosial antara penghuni dengan penghuni lainnya relatif berbeda termasuk karakteristik penghuninya, baik antara penghuni barak konvensional, modifikasi, dan semi kost. Perbedaan nampak dalam hal status sosial, ekonomi, asal usul keluarga, termasuk sikap sosial sehari-hari di lingkungannya. Ada kecenderungan bahwa penghuni barak konvensional umumnya berasal dari daerah (udik) dengan tingkat ekonomi yang relatif rendah. Walaupun secara ekonomi mereka relatif kurang, namun dalam interaksi sehari-hari sikap sosial seperti kebersamaan, tolong-menolong bahkan tumbuh sikap kekeluargaan dengan penghuni lainnya.

Sedangkan penghuni barak modifikasi lebih cenderung pada sikap yang relatif individualistis, acuh tak acuh, masa bodoh, lebih mementingkan perilaku dirinya, terlebih dalam perilaku-perilaku menyimpang lainnya, seperti memasukan pacar ke kamar.

Keadaan tersebut bisa diperkuat dengan bentuk fisik dan desain barak yang secara fisik akan memberi peluang untuk secara bebas untuk memasukan pacar ke dalam kamar, tanpa ada orang lain untuk melihatnya. Misalnya bentuk sekat teras kamar atau barak yang bisa orang lain tidak berani untuk masuk ke teras tersebut, walaupun tinggal berdampingan bertetangga, ditambah kurangnya perhatian dan acuh tak acuhnya pemilik barak terhadap penghuninya.

FIRO adalah singkatan dari Fundamental Interpersonal Relations Orientation (Orientasi dasar dari Hubungan-hubungan Antarpribadi). Teori ini dikemukakan oleh Schutz $(1955,1958$; dalam Sarlito Wirawan Sarwono, 2010:147) pada dasarnya mencoba menerangkan perilakuperilaku antarpribadi dalam kaitannya dengan orientasi (pandangan) masing-masing individu lainnya.

Ide pokoknya adalah bahwa setiap orang mengorientasikan dirinya kepada orang lain dengan cara tertentu (khas) dan cara ini merupakan faktor utama yang mempengaruhi perilakunya dalam hubungan antarpribadi

\subsection{Interaksi Sosial Mahasiswa dengan Pemilik Barak, Penjaga Barak, dan Ketua RT}

Ada kecenderungan interaksi antara mahasiswa, pemilik barak relatif jarang di lakukan, karena mahasiswa cendrung cuek dan pemilik barak pun kurang memberi perhatian terhadap penghuni barak tersebut, bahkan jarang memperhatikan tingkah laku atau kebiasaan mahasiswa, kecuali pada saat bayar barak. Kecuali interaksi dengan pemilik barak semi kost.

Hal yang sama juga terjadi kurangnya interaksi antara penghuni barak dengan RT, paling-paling ketika ada undangan kegiatan atau minta surat keterangan tidak mampu, bahkan untuk melapor sebagai anggota masyarakat pun, sebagian mahasiswa tidak melapor ke RT sehingga menjadi persoalan bagi RT itu sendiri.

Teori ini memiliki bentuk-bentuk perilaku sosial sebagaimana dikutip oleh Wallace dan Wolft (1986: 145-186; dalam Hasym Nawawie, 2009:69). Bentuk-bentuk perilaku sosial yang dimaksudkan adalah sebagai berikut;

(1) Proposisi Keberhasilan, dalam segala hal yang dilakukan oleh seseorang, semakin sering sesuatu tindakan mendapatkan ganjaran (mendatangkan respon yang positif dari orang lain) maka akan semakin sering pula tindakan akan dilakukan oleh orang yang bersangkutan. (2) Proposisi Stimulus, Jika suatu stimulus tertentu telah merupakan kondisi di mana tindakan seseorang mendapatkan ganjaran maka secara stimulus yang ada dengan stimulus 
tersebut akan semakin besar kemungkinannya bagi orang itu untuk mengulang tindakannya seperti yang ia lakukan pada waktu yang lalu. (3) Proposisi Nilai, Semakin bermanfaat hasil tindakan seseorang bagi dirinya maka akan semakin besar kemungkinan tindakan tersebut diulangi. Proposisi rasionalitas yang merupakan kombinasi tiga proposisi yang ada menyatakan bahwa didalam memilih suatu tindakan diantara alternatif tindakan yang mungkin dilaksanakan maka seseorang akan memilih yang paling menguntungkan dilihat dari segi waktu, nilai, hasil (V) dan perkembangan berdasar kemungkinan pencapaian hasil (P). (4) Proposisi Kejenuhan-Kerugian, Semakin sering seseorang menerima ganjaran yang istimewa maka ganjaran tersebut akan menjadi kurang bermakna; (5) Proposisi Persetujuan Perlawanan, (a) Jika seseorang tidak mendapat ganjaran seperti ia inginkan atau mendapat hukuman yang tidak ia harapkan ia akan menjadi marah dan akan semakin besar kemungkinan bagi orang tersebut untuk mengadakan perlawanan atau menentang dan dari hasil tingkah laku semacam ini akan menjadi lebih berharga bagi dirinya; (b) Bila tindakan seseorang mendatangkan ganjaran seperti yang ia harapkan bahkan berlebihan atau tindakan tersebut tidak mendatangkan hukuman seperti keinginannya maka ia akan merasa senang dan akan semakin besar kemungkinannya bagi orang tersebut untuk menunjukkan tingkah laku persetujuan terhadap tingkah laku yang dilakukan, dan hasil tingkah laku semacam ini akan menjadi semakin berharga dari dirinya.

\subsection{Perilaku Sosial yang Terbentuk dalam}

\section{Proses Interaksi Sosial Mahasiswa}

\section{dalam Kehidupan Barak}

\subsubsection{Perilaku Akademik}

Umumnya penghuni barak tidak belajar secara rutin hanya pada saat-sat tertentu saja, misalkan ketika ada tugas individu maupun kerja kelompok. Belajar hanya dilakukan pada saat keesokan harinya ada ujian saja. Belajar hanya di lakukan pada saat di perkuliahan saja. Setelah pulang kuliah biasanya jalan-jalan, belanja ke pasar atau mall. Pulang dari aktivitas tersebut paling hanya tidur-tiduran, nonton TV, main PS, nongkrong dengan teman-teman, dan jalan-jalan dan aktivitas tersebut berlangsung begitu setiap harinya.

\subsubsection{Perilaku Agamis}

Kehidupan mahasiswa di barak sangat bebas dan sulit untuk di kontrol baik oleh orang tua ataupun pemilik barak, kecenderungan perilaku mahasiswa berpeluang untuk melakukan perilaku menyimpang dan meninggalkan kewajibannya untuk belajar dan melupakan tujuan utama untuk kuliah, termasuk jarangnya melakukan kegiatan keagaamaan.

Teori yang mengkaji individu adalah psikoanalisa dari Freud (Munandar Soelaeman, 2008:48). Ia membedakan tiga sistem dalam hidup psikis yaitu, Id, Ego, dan Superego. Istilah dalam psikoanalisa dikenal sebagai tiga "instansi" yang menandai hidup psikis..

Instansi pertama $I d$ adalah lapisan psikis yang paling dasar terdiri dari naluri-naluri bawaan ( seksual dan agresif) dan keinginankeinginan yang direpresi. Id tidak terpengaruh control Ego dan prinsip realitas. Pada Id yang berkuasa prinsip kesenangan yang tidak mengenal waktu dan tidak mengenal hukumhukum logika.

Instansi kedua Ego adalah hasil deferensiasi dari $I d$ karena kontak dengan dunia luar. Ego (bukan pengertian aku) aktivitasnya dapat sadar, prasadar atau tidak sadar. Contoh aktivitas sadar adalah persepsi lahiriah, persepsi batiniah, dan proses-proses intelektual, aktivitas prasadar contohnya fungsi ingatan. Aktivitas tak sadar Ego dijalankan dengan mekanismemekanisme pertahanan (defence mechanisms). Potensi Ego dikuasai oleh prinsip realitas seperti pemikiran obyektif yang sesuai dengan tuntutantuntutan social dan rasional dan diungkapkan melalui bahasa. Tugas Ego adalah mempertahankan kepribadiannya, adaptasi dengan lingkungan, menghilangkan konflik dengan realitas dan mendamaikan konflik-konflik berbagai keinginan agar selaras. Ego berfungsi pula sebagai filter apa-apa yang masuk ke sifat sadar dan apa-apa yang akan dikerjakan. Dapatlah dikatakan bahwa Ego berfungsi sebagai penjamin kesatua pribadi dan alat sintesa.

Instansi ketiga Superego terbentuk hasil internalisasi, yaitu pembatinan dari norma-norma atau nilai-nilai yang dating dari luar, diolah sedemikian rupa sehingga sehingga terpencar dari dalam. Superego adalah potensi hasil dari proses internalisasi, sehingga menjadi miliknya berasal dari subjeknya sendiri, meskipun sebelumnya berasal dari luar dirinya. Aktivitas Superego dinyatakan dengan konflik dengan Ego yang dirasakan dalam emosi-emosi seperti rasa bersalah, rasa menyesal dan lain sebagainya. Sikap mawas diri, kritik diri dan inhibisi adalah berasal dari Superego.

Ketiga instansi, Id, Ego, dan Superego potensinya pada setiap individu berbeda-beda. Ada individu yang tekanannya lebih kuat pada Superego dan lemah pada Id dan Ego, pokoknya ketiga instansi itu bervariasi kekuatannya pada setiap individu. 
Teori ini, dapat membantu menjelaskan berbagai interaksi individu dengan dirinya atau peranan lingkungan dalam mempengaruhi potensi ketiga intansi tersebut, misalnya pada lingkup perilaku sosial mahasiswa yang terkait dengan perilaku keagamaan dalam kehidupan barak di Kota Palangka Raya.

\subsubsection{Perilaku Menyimpang}

Realita di lapangan ditemukan bahwa dari 35 mahasiswa yang tinggal di barak, 27 orang $(77,14 \%)$ pernah melakukan sex pranikah dengan pacarnya dan menjadi perilaku yang lumrah di kalangan mahasiswa, bahkan ada juga yang bisa di bawa oleh om-om dengan bayaran antara satu juta sampai satu juta limaratus ribu rupiah.

Keadaan tersebut mencerminkan kebebasan para mahasiswa di barak tempat mereka tinggal, kiranya dengan mudah mendapatkan penjelasan dan informasi dari mahasiswa tersebut bahkan tanpa malu dan vulgar.

Tommy F. Awuy. (2007). Seks, uang dan kekuasaan merajut sedemikian rupa dan mendominasi kehidupan manusia konteporer, khususnya kaum urban. Nilai kenikmatan biasanya muncul jauh lebih besar dan dengan demikian dikejar ketimbang nilai ideal tentang kebenaran. Spontanitas keindrawian sering kali menampik atau mendesak potensi refleksif untuk mundur sehingga apa yang dirasakan atau saksikan, realitas keseharian menjadi semacam permainan gairah (desire) semata.

\subsubsection{Pinjam Barak/ Pinjam Kamar}

"Pinjam Barak dan Pinjam Kamar" adalah istilah yang lazim diantara mahasiswa penghuni barak untuk memberikan pinjaman tempat tinggal (barak) ke teman untuk sementara waktu, pinjaman diberikan kepada teman yang benarbenar dianggap akrab ataupun kepada saudaranya sendiri. Biasanya teman yang dianggap akrab atau saudara tersebut mengungkapkan untuk meminjam kamarnya, dengan berbagai alasan disampaikan ke penghuni barak tersebut. Misalnya ada yang meminjam kamar dengan alasan untuk mengetik tugas, istirahat, mengerjakan tugas, termasuk untuk "pacaran", ada juga buat tempat minumminuman (mabuk-mabukkan) bahkan yang datang dari kampungpun bisa meminjamnya, baik teman akrab ataupun saudaranya.

Modus operandinya, ketika penghuni barak lagi kuliah, biasanya teman akrab tersebut akan meminjam tempat kost, kalau kuliah mulai jam tujuh sampai jam dua belas, maka si penghuni tidak berani pulang ke baraknya, paling-paling pulangnya ikut dulu ke tempat barak teman lainnya ataupun jalan-jalan dulu, ketika penghuni barak akan pulang, biasanya penghuni mengirimkan SMS seakan memberi sinyal kepada peminjam untuk siap-siap, bahwa penghuni akan pulang. Hal yang sama juga terjadi ketika penghuni lagi pulang kampung, karena peminjam akan lebih leluasa menggunakan barak tersebut.

\subsubsection{2. “V-PB dan Om-om"}

"V" dan "PB" adalah inisial yang dipilih peneliti untuk menggantikan nama sebenarnya dari tempat diskotik yang ada di Palangka Raya, sedangkan om-om yang lumrah dikenal oleh mahasiswa sebagai orang yang biasa mengajak untuk menemani bahkan "menemani" ke diskotik, minum, bahkan ke taraf untuk memuaskan nafsunya. Dari beberapa informan memberi jawaban bahwa berawal dari kenalan dengan tetangga satu kost-nya, berlanjut dengan tanya-tanya tentang kesukaan untuk ke diskotik sampai berlanjut dikenalkan dengan om-om. Berawal dari situlah aktif ke beberapa diskotik, dari mulai iseng-iseng, menemani om-om sampai dengan bayaran jutaan rupiah

\subsubsection{3. "Gigolo, PSK dan Lesbian"}

Perilaku gigolo menjadi realita sosial yang terjadi dan ada di sekitar mahasiswa dalam kehidupannya di barak, walaupun secara presentase tidak ditemukan jumlah secara pasti, tapi fakta itu ada dalam lingkungannya. Seperti yang diungkapkan informan yang terkait dengan keberadaan gigolo dalam kehidupan barak mahasiswa, sehingga terjadi hubungan seks untuk mendapatkan uang dan lumrah untuk mahasiswa tertentu, bahkan ada juga yang menjual teman ke om-om dengan pasaran ratusan sampai satu jutaan permalam. Tidak hanya adanya perilaku gigolo, juga di barak lingkungan mahasiswa ada praktik dan perilaku menyimpang yang dilakukan dengan PSK. Informan lain juga mengungkapkan bahwa terjadi interaksi antara PSK dengan mahasiswa yang tinggal di barak, bahkan sering kali kumpulkumpul dan berinterkasi sehingga menjadi akrab antara mahasiswa penghuni barak dengan PSK. Bila PSK mendapatkan uang yang banyak biasanya mengundang mahasiswa dan langsung belanja seperti beli bir, beli minuman-minuman, beli makanan untuk makan bersama dengan mahasiswa.

Perilaku menyimpang lainnya yang terjadi dalam kehidupan barak adalah adanya perilaku menyimpang seperti "lesbian". Perilaku lesbian mahasiswa di barak ternyata tidak saja bisa pacaran sesama jenis, juga bisa menghasilkan 
uang, juga pakaian dari pemberian pacar sesama jenisnya.

\subsubsection{Ketat yang Semu}

Tidak sedikit orang tua menganggap bahwa barak atau tempat kost yang dilengkapi fasilitas yang cukup seperti tempat tidur, lemari, dapur dan penjaga yang ketat dengan aturan yang ketat pula dengan sejumlah protokoler dapat memberikan keamanan dan kenyamanan bagi penghuninya. Jam kunjung dibatasi, tempat tamu tersedia khusus, adanya ijin untuk ke luar bagi penghuni, keadaan tersebut bisa merupakan kondisi yang dapat mengurangi perilaku tindakan yang keluar dari batas-batas kewajaran.

Fakta di lapangan, hasil wawancara dengan penghuni barak yang terkait dengan ketentuan-ketentuan yang ketat pada barak yang ditempatinya akan memberikan kepastian aturan dan kenyamanan bagi penghuninya, namun di sisi lain masih memberi peluang untuk berbuat semuanya di luar barak itu sendiri. Sedangkan penjaga lebih fokus terhadap ketertibaan di dalam (kost) sendiri, ketimbang perhatian perilaku di luar kost.

\subsection{Pandangan Tokoh Agama dan Tokoh Pendidikan}

Dalam memahami dan memaknai fenomena yang terjadi dalam kehidupan barak di Kota Palangka Raya, diantara tokoh agama, tokoh pendidikan, dan pakar budaya menyatakan bahwa kehidupan di barak yang bersifat penyimpangan perilaku tersebut merupakan perilaku sosial yang tidak bisa dihindari bahkan bisa terjadi dimana-mana. Secara empirik realita sosial yang ada di masyarakat tersebut, tidak bisa sekaligus hilang begitu saja, namun memerlukan komitmen bersama bahkan yang paling utama adalah harus ada dan datang dari sendiri untuk memperbaikinya, bahkan tidak benar bila masyarakat "menghakimi" mahasiswa tersebut untuk keluar dari tatanan masyarakat yang ada di sekitarnya. Rangkullah, dan bawalah mahasiswa tersebut untuk bergabung untuk memperbaiki imannya sehingga menjadi kuat. Solusi yang dapat diberikan, yang terkait perilaku sosial yang menyimpang dimasyarakat tersebut,

\section{E. E. KESIMPULAN DAN}

\section{REKOMENDASI}

\subsection{Kesimpulan}

Berdasarkan hasil analisis dan pembahasan pada bab sebelumnya, maka dapat disimpulkan halhal sebagai berikut:

a. Interaksi mahasiswa yang tinggal di barak konvensional dan barak semi kost menunjukkan perilaku sosial seperti kebersamaan, tolong-menolong bahkan tumbuh perilaku kekeluargaan seperti saling menjenguk bila ada yang sakit. Sedangkan pada barak modifikasi ada kecenderung individualistis, acuh tak acah, dan masa bodoh terlebih bila penghuni berperilaku yang menyimpang. Hal yang sama juga terjadi pada barak konvensional yang tidak ada dan/atau jauh dari pemiliknya cenderung penghuninya relatif lebih bebas, dan cuek terlebih yang terkait dengan masalah "pribadi".

b. Interaksi mahasiswa yang tinggal di barak konvensional dan barak modifikasi dengan pemiliknya dilakukan sebulan sekali pada saat bayar pembiayaan sewa barak. Sedangkan interaksi mahasiswa yang tinggal pada barak semi kost dengan pemiliknya selalu dilakukan, selain pemilik/penjaga tersebut tinggal bersama dalam satu lokasi juga ditanamkan sikap kekeluargaan sesama penghuni dan pemiliknya.

c. Komunikasi dan interaksi mahasiswa yang tinggal di barak modifikasi dan barak semi kost dengan ketua RT tidak pernah dilakukan, bahkan ketika datang, keluar, maupun pindah barak-pun tidak melapor, termasuk tempat ketua RT-nya pun tidak tau tempatnya. Sedangkan interaksi mahasiswa yang tinggal di barak konvensional dengan ketua RT dilakukan pada saat ada undangan kegiatan, ataupun untuk meminta surat keterangan tidak mampu.

d. Pola belajar mahasiswa yang tinggal di barak konvensional dan barak modifikasi cenderung tidak ada belajar kecuali saat mau ujian dan ada tugas. Sedangkan pada barak semi kost, selain belajar di kampus juga belajar di barak (tempat khusus) yang telah disediakan oleh pemilik barak.

e. Kegiatan keagamaan mahasiswa yang tinggal di barak modifikasi dan semi kost selain melaksanakan kegiatan dan membentuk forum keagamaan juga mengadakan yasinan, pengajian dan sholat berjamaah. Sedangkan Kegiatan keagamaan mahasiswa yang tinggal di barak konvensional, dilakukan hanya karena ikutikutan dan menghargai teman yang mengajak saja.

f. Perilaku mahasiswa yang tinggal di barak semi kost relatif tertib, sedangkan mahasiswa yang tinggal di barak konvensional dan barak modifikasi relatif cenderung bebas bahkan ada perilaku seperti mabok, seks pranikah bahkan adanya PSK. 


\subsection{Rekomendasi}

Berdasarkan kesimpulan dari penelitian ini, maka saran yang dapat disampaikan adalah sebagai berikut.

a. Penelitian ini menggunakan penelitian pendekatan kualitatif dalam hal pengumpulan data dan analisis data peneliti sudah berusaha secara maksimal, namun disadari hasil kajian ini belum bisa menyentuh seluruh aspek kehidupan mahasiswa di barak Kota Palangka Raya. Oleh karena itu, masih terbuka untuk meneliti lanjutan dengan melibatkan berbagai aspek dan dimensi lainnya sebagai pengembangan khasanah keilmuan.

b. Berbagai teori ilmu sosial dapat dijadikan teorical orientation untuk mencermati fenomena sosial. Baik yang bersifat klasik, modern, dan neomodern, seperti teori tindakan sosial Weber dan teori lainnya. Oleh karena itu, fenomena sosial berupa pola perilaku mahasiswa dalam kehidupaan barak untuk dikaji kembali dalam penelitian lanjutan dengan melibatkan sejumlah aspek lainnya.

c. Hasil penelitian ini diharapkan akan mampu dan menjadi bahan tambahan bagi peneliti lainnya, para mahasiswa, para praktisi dalam memahami fenomena perilaku sosial mahasiswa khsusnya dan perilaku masyarakat lainnya.

\section{F. REFERENSI}

A.Hasyim Nawawie. (2009). "Perilaku Sosial Mayarakat Terhadap Pekerja Abak. Disertasi. Universitas Merdeka Malang. Program Pascasarjana.

Bachtiar, H. W. (1984). "Integrasi Nasional Indonesia", Wawasan Kebangsaan Indonesia. Jakarta: Bakom PKB Pusat.
Dadang Hawari. (1997). Alquran, Ilmu Kedokteran Jiwa dan Kesehatan Jiwa. Cetakan III. Jakarta: Dana Bhakti Prima Yasa.

Djunaidi, Dhony. (1997). Dasar-dasar Penelitian Kualitatif: Prosedur, Teknik, dan Teori Grounded disadur dari Basics of Qualitative Research: Grounded Theory Procedures and Techniques (Aselm Strauss \& Julied Corbin). Suarabaya: Bina Ilmu.

Johnson, Doyle Paul. (1998). Sociologicaltheory Classical Founders and Contemporary Perspective. Jilid I. Terj. Robert MZ. Lawang, Jakarta: Gramedia

Masinambow, E.K.M. (1997). Pengantar: Koetjaraningrat dan Antropologi di Indonesia, dalam buku Koentjaraningrat dan Antropologi di Indonesia. Jakarta: AAIbekerjasama dengana Yayasan kObor.

Munandar Soelaeman. (2008). Ilmu Sosial Dasar. Teori dan Konsep Ilmu Sosial. Bandung: PT. rafika Aditama

Sarlito W. Sarwono. (2010). Psikologi Remaja. Jakarta: PT. Rajagrafindo Persada.

Tommy F. Awuy. (2007). "Gairahnya Emka". Jakarta Undercover. Jakarta: GagasMerdia.

KBBI. 2011. Kamus Besar Bahasa Indonesia (KBBI). [Online] Available at: http://kbbi.web.id/pusat, [Diakses 23 Februari 2011] 